\title{
G-BANDING ANALYSES OF MALE CHROMOSOMES IN APIS CERANA AND A. MELLIFERA LIGUSTICA
}

\author{
By Hidehiro HOSHIBA and Ichiji OKADA \\ Daito Bunka University, Dai-Ichi High School, Itabashi, Tokyo, 175 \\ and Department of Agriculture, Tamagawa University, Machida-shi, Tokyo, 194
}

\section{SUMMARY}

Karyotype and G-banding patterns in the somatic division of Apis cerana japonica were compared with $A$. mellifera in this paper.

Sixteen chromosomes of this species were divided into two groups, metacentric (nos. 1-4) and submetacentric (nos. 5-16), same as in A. mellifera. The cyto-taxonomical difference between these two species was established by the region less reactive to Giemsa staining. This was in the shorter arm of chromosome no. 2, supposedly the nucleolus organizing region. The G-banding patterns were almost the same in the both species.

\section{INTRODUCTION}

Recent cytological studies of the honeybee made clear that the chromosome number of the genus Apis was 16 in haploid males (FARENForst, 1977). The chromosome number of diploid males and female was counted in $A$. mellifera (Hoshiba, 1979), and in A. cerana japonica (Hoshiba et al., 1981).

The detailed karyological and banding analyses of $A$. mellifera were proposed in the haploid male (Hoshiba, 1984 a) and the diploid male and the female (Hoshiba, 1984 b).

There have been some biometric (OKADA et al., 1956; MORIMOTO, 1965, 1968 ; RutTNER, 1978 ; ChOI, 1985), chemical (TANABE et al., 1970), genetic (RUTTNER and MaUl, 1983) and cytological (DeOdiKar and ThaKar, 1966 ; FAHRENHORST, 1977) data on the taxonomic or evolutionary relationships between $A$. cerana and $A$. mellifera. No interspecific differences have been found in the karyological studies.

The distinct karyological and G-banding analyses of the haploid male of $A$. cerana japonica, compared with $A$. mellifera, are presented in this paper from the cytotaxonomic point of view. 


\section{MATERIALS AND METHODS}

Young male larvae (3-4 instar) of $A$. cerana japonica, and A. mellifera ligustica, a mixed strain widely distributed in Japan were dissected to obtain the testes. These testes were pretreated in a hypotonic solution $(0.4 \% \mathrm{KCl}, 0.01 \%$ colchicin) for $30 \mathrm{~min}$, fixed in acetic acid-methanol $(1: 3)$ and stored at about $-20^{\circ} \mathrm{C}$.

The preparations were made by the usual air dry method (TAKAGI, 1971), and stained with Giemsa solution. They were then decolored by means of acetic methanol. The tripsin method (SEABright, 1971) was used to determine the G-banding.

\section{RESULTS AND DISCUSSION}

The chromosome number of the haploid set of $A$. cerana japonica was 16 . This set consists of 4 metacentric nos, 1-4), 12 submeta- or subtelocentric chromosomes (Fig. 1). The G-banding karyotype pattern of $A$. cerana japonica and $A$. mellifera are illustrated in Fig. 1 and 2, respectively. As HoshibA et al. (1981) mentioned, the karyotype and the G-banding pattern were similar to those of $A$. mellifera except for chromosome no. 2. Especially in the early meta-
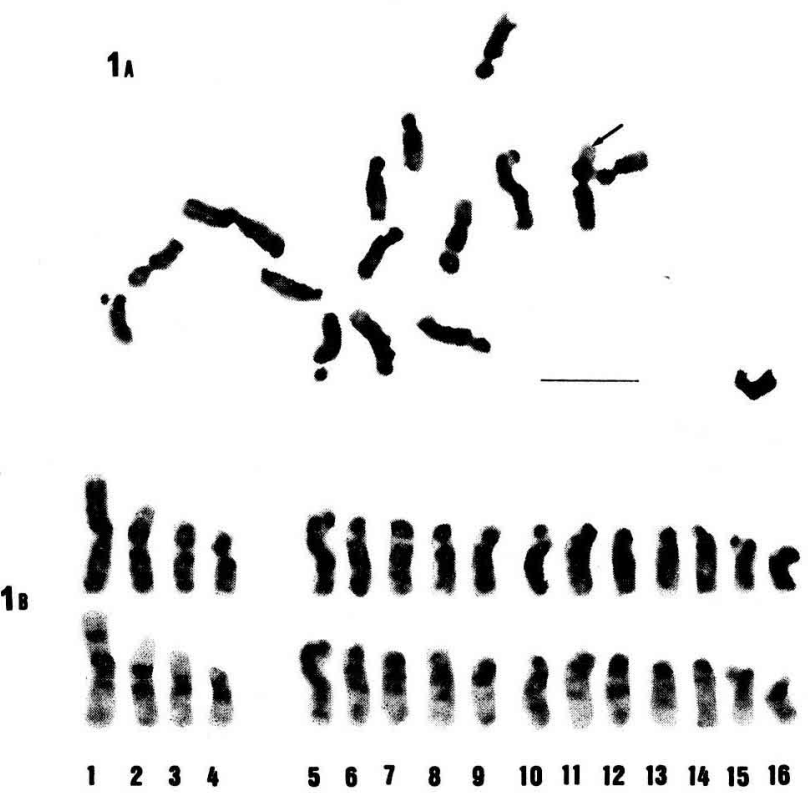

FIG. 1. - Mitotic metaphase chromosome of Apis cerana japonica $(A)$ and its G-banding karyotype pattern $(B)$

The less reactive region to Giemsa staining was observed (arrow) in the no. 2 chromosome of this species. Bar indicates $5 \mu \mathrm{m}$. 

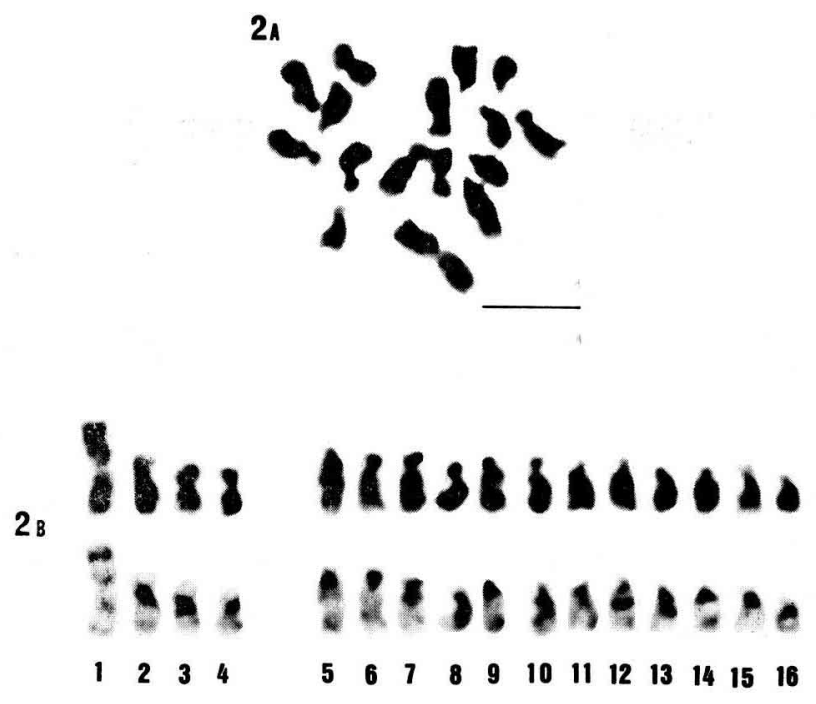

Fig. 2. - Mitotic metaphase chromosomes of Apis mellifera $(A)$ and its G-banding karyotype pattern (B)

Bar indicates $5 \mu \mathrm{m}$.
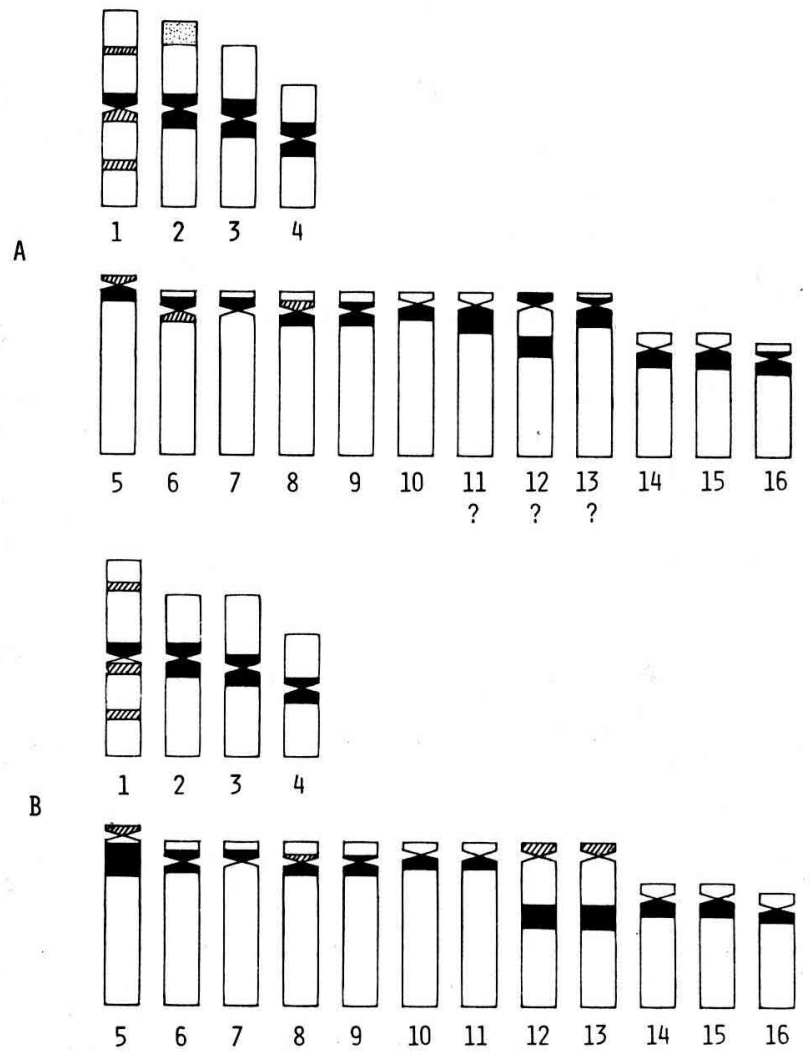

FIG. 3. - Schematic G-banding pattern of Apis cerana japonica (A) and Apis mellifera (B) 
phase cell, no. 2 in $A$. cerana japonica was characterized by a region less reactive to Giemsa staibning in the shorter arm. This is supposed to be a nucleolus organizing region. This region has not been found in $A$. mellifera so far studied. Thus, the cytotaxonomical difference between $A$. mellifera and $A$. cerana was established. However, the karyotype analyses of the other local sub-species of A. cerana in Asia, and other analyses such as C- or NOR-banding methods are required for further investigation. The G-banding pattern of each chromosome was almost the same in the two species, except for the occurrence of some undetermined chromosomes in A. cerana japonica (Fig. 3 b). WOYKe (1973), RUTTNER and MAUL (1983) and HoshrBa, unpublished) instrumentally inseminated between these species. The only embryological investigation of hybrids was made by RUTTNER and MAUL (1983), they found that eggs laid by intercrossed queens developed into an embryonic stage, i.e., each chromosome must be paired for a certain period. There have been no examples of successful hybrid production by natural matings in Japan, where both species exist, in spite of some successful examples (HACHINOHE, personal communication, 1985) by instrumental insemination and by natural mating (VATS, 1953). Attempts to make hybrid are difficult from the karyo-morphological view point.

Received for publication in 1985.

Accepted for publication in December 1985.

\title{
ACKNOWLEDGMENTS
}

The authors wish to express their sincere appreciation to Professor Emeritus, Dr. S. Makino, M.J.A. of Hokkaido University and Professor Dr. F. RutTNer for his helpful suggestions for the improvement of this manuscript. We are also greatly indebted to the following : Professors Dr. S. SAKaI of Daito Bunka University, and Dr. H. Yamamoto of Dokkyo University of Medicine.

\section{ZUSAMMENFASSUNG}

\author{
G-BANDEN ANALYSE DER MANNLICHEN CHROMOSOMEN \\ VON APIS CERANA UND A. MELLIFERA LIGUSTICA
}

\footnotetext{
Karyotyp und G-Banden Muster bei der somatischen Teilung von Apis cerana japonica wurden mit denen von $A$. mellifera verglichen.

Die 16 Chromosomen dieser Art können in zwei Gruppen eingeteilt werden, metazentrische (Nr. 1-4) und submetazentrische (Nr. 5-16), genau so wie bei $A$. mellifera. Die cyto-taxonomische Differenz zwischen den beiden Arten manifestiert sich in einer Region, die weniger gut auf die Giemsa Färbung anspricht. Sie liegt im kürzeren Arm des Chromosoms Nr. 2 und ist wahrscheinlich der Nucleolenbildungsort. Die G-Banden Muster der beiden Arten sind ziemlich gleich.
} 


\section{RESUME \\ ANALYSE DES BANDES G DES CHROMOSOMES DES MÂLES D'APIS CERANA JAPONICA ET D'A. MELLIFICA LIGUSTICA}

On a comparé le caryotype et le spectre des bandes $\mathrm{G}$ lo:s de la division somatique chez Apis cerana japonica et A. mellifica ligustica.

Chez les deux espèces, les 16 chromosomes peuvent être séparés en 2 groupes, l'un métacentrique ( $\mathrm{n}^{\circ}$ 1-4), l'autre submétacentrique ( $\mathrm{n}^{\circ}$ 5-16). La différence cyto-taxonomique entre les 2 espèces se manifeste par une région qui réagit moins bien à la coloration de Giemsa. Elle est située dans le bras le plus court du chromosome $\mathrm{n}^{\circ} 2$ et supposée être le lieu de formation du nucléole. Les spectres des bandes $G$ sont presque semblables chez les 2 espèces.

\section{REFERENCES}

Deodikar G.B., 1966. - Cyto-genetics of Indian honeybee and bearing on taxonomic and breeding problems. Indian J. Genet. Pl. Breed., 25 A, 386-393.

Fahrenhorst H., 1977. - Nachweis übereinstimminder Chromosomen-Zahlen $(n=16)$ bei allen 4 Apis-Arten. Apidologie, 8, 89-100.

Hoshiba H., 1979. - Chromosome of diploid and haploid drone honeybee, Apis mellifera. XXVII Int. Beekeep. Congr., 73-74.

Hoshiba H., 1984 a. - Karyotype and banding analyses on haploid males of the honey bee (Apis mellifera). Proc. Japan Acad., 60 B, 122-124.

Hoshiba H., $1984 \mathrm{~b}$. - The C-banding analysis of the diploid male and female honeybee (Apis mellifera). Proc. Japan Acad, 60 B, 238-240.

Hoshiba H., Okada I., Kusanagi A., 1981. - The diploid drone of Apis cerana japonica and its chromosomes. J. Apic. Res., 20, 143-147.

LEE M.L., 1985. - Biometrical studies on the variation of some morphological characters in Korean honeybees, Apis cerana F. and A. mellifera L. M.S. Thesis, Seoul National Univ., 42 pp.

Morimoto H., 1965. - Investigations on a measuring abdorminal size in worker honeybees, Apis mellifera ligustica and Apis cerana cerana. J. Apic. Res., 4, 17-21.

MoRimoto H., 1968. - The use of the labial palpus as a measure of probocis length in worker honeybees, Apis mellifera ligustica and Apis cerana cerana. J. Apic. Res., 7, 147-150.

Okada I., Sakai T., Hasegawa M., 1956. - Notes on some morphological characters of Japanese honeybee. Kontyu, 24, 145-154 (in Japanese with English summary).

RUTTNER F., 1978. - Biometrical-statical analysis of the geographic variability of Apis mellifera $\mathbf{L}$. Apidologie, 9, 363-381.

Ruttner F., Maul V., 1983. - Experimental analysis of reproductive isolation interspecies isolation of Apis mellitera L. and Apis cerana Fabr. Apidologie, 14, 309-327.

Seabright M., 1971. - A rapid banding technique for human chromosomes. Lancet, ii, $971-972$.

TaKaGI N., 1971. - A simple technique to demonstrate the centromeric "heterochromatin " in the mouse and other animals. Japan J. Genetics, 46, 361-363.

Tanabe Y., Tamakı Y., Nakano S., 1970. - Variations of esterase isozymes in seven species of bees and wasps. Japan J. Genetics, 45, 425-428.

Vats B.R., 1953, - Breeding Italian bees in Kashmir. Kashmir, 3, 23-24, 33.

WoYke J., 1973. - Instrumental insemination of Apis cerana indica queens. J. Apic. Res., 12, 151-158. 